Ethiopian Journal of Environmental Studies \& Management 7(1): 1 - 12, 2014

ISSN:1998-0507

doi: http://dx.doi.org/10.4314/ejesm.v7i1.1

Submitted: August 7, 2013

Accepted: January 7, 2014

\title{
THE SOCIO - ECONOMIC CHARACTERISTICS OF COMMUNITIES AT THE DOWNSTREAM SECTOR OF JEBBA DAM, NIGERIA
}

\author{
*ADEBOLA, A.0., ${ }^{1}$ GARBA, I.K., ${ }^{1}$ AHMED S.A., ${ }^{1}$ MUHAMMED, ${ }^{\text {M. }}{ }^{1}$ AND KUDU, D. ${ }^{2}$ \\ ${ }^{1}$ Department of Geography, Federal University of Technology, Minna, Niger State, Nigeria \\ ${ }^{2}$ Department of Geography, Ibrahim Badamasi Babangida University, Lapai. Niger State
}

\begin{abstract}
Downstream communities have been neglected in dam construction planning process in Nigeria.. A survey was carried out on some randomly selected downstream communities of Jebba dam namely Gungu, Gana, Fanga, Bele, Bere, Gaba and Baru communities, using structured interviews administered to people in the selected communities. The research result showed that the Jebba dam has negative effect on settlements downstream. About 5\% of the houses in each of the villages have been displaced and the value of land has also depreciated by $20 \%$. Farming and fishing in various communities have been affected due to land appropriation, flooding and soil erosion. Only Gungu and Gana are connected to electricity supply while road accessibility is very poor in all the villages except Gungu and Gana. The impacts of these changes are magnified by changes in the flow pattern of The River Niger downstream that is caused by the operations of the dam. These changes, whether in total streamflow in seasonal timing or in short-term, even hourly fluctuations in flows, generate a range of impacts on The River. This is because the aquatic lives in and around the river is tightly linked to the existing flow patterns of river. It is recommended that all villages that are affected by the activities of the dam should be connected to the national grid; this will enhance the socioeconomic activities in the area. It is also suggested as a principle that 'a programme to monitor the impacts of dam development (particularly in downstream communities) should be an integral element of the planning process, and should be matched by resources to mitigate impacts not addressed fully by the planning processes.
\end{abstract}

Key words: Downstream Communities, Socio-economic, sector, Dam, Characteristics, Flow pattern

\section{Introduction}

There has been increasing recognition by both dam proponents and dam opponents that the social impacts of dam are complex, and can be far-reaching. Social impacts can be positive (e.g. improved welfare resulting from new access to irrigation water, improved fishing upstream) or negative (e.g. resettlement, decline in downstream fishing due to flood control). Social impacts can be direct (such as cultural trauma of involuntary resettlement), or the result of a cascade, where environmental impacts generate economic impacts, and these in turn cause social impacts (for example the impacts of changes in a river's flooding patterns reducing fish populations downstream of a dam, affecting the economic return from fishing and causing increased levels of out-migration of fishermen). Social impacts can be local to the dam site (Adams, 2000).

Dams and their corresponding reservoir generally are designed to be multipurpose structures. People, who support the construction of dams and reservoirs, point out that reservoirs may be useful for recreational activities and generating electricity as well as providing flood control and ensure a more stable water supply. However, it is often difficult to reconcile these various uses at a given site. For a variety of reasons that include, displacement of people, loss of land, loss of wildlife and permanent adverse change of river ecology and hydrology many people today are vehemently against turning remaining rivers into reservoirs (Carney, 1998).

*Corresponding Author: Adebola, A.O.

Email: abiodunalawode@yahoo.com 
There is little doubt that if our present practices of water use (Hydroelectric Power generation, industrial, domestic and agricultural uses) continue, we will need additional dams and reservoirs and some existing dams will be heightened to increase water storage. However, as there are few acceptable sites for new dams, conflicts over the construction of additional dams and reservoirs are bound to occur. Water developers may view a canyon dam site as a resource for water storage, whereas environmental managers may view it as a wilderness area and recreation site for future generation.

As some countries are thinking of dam removal as solution to environmental problems, China is building the world's largest dam on the Yangtze River (Botkin \& Keller, 2003). From whichever angle dam construction is viewed there are health hazards from hydro-power schemes due to their often polluted or erratic nature, pollution reduces access to portable water for communities that rely on the river thereby promoting the transmission of water borne diseases.

The generic process of Environmental Impact Assessment (EIA) was institutionalized in the United States as a requirement of the country's National Environmental Policy Act of 1969 (NEPA) which was signed into law at the beginning of 1970. In the three and half decades of its existence, EIA has evolved considerably in scope, tools, techniques and methodology (Nwafor, 2006).

Downstream impacts have been the focus of debates about dams: unrecognized, misunderstood and underestimated by planners. One reason for this is that they occur in remote areas, far from the dam site, and are all too easily ignored. Even when recognized, downstream impacts are daunting in their complexity in space and time. The construction of dams in Nigeria is given too much of structural or engineering consideration with little or no environmental impact assessment of the operations after the design and construction. The environmental problems as a result of operation are usually devastating, thus the need for impact assessment.

The constructions of canal systems, especially in developing countries have led to serious, unanticipated socio-economic problems. For example when the high dam on Nile River at Aswan, (Egypt) was completed in 1964, a system of canals was built to convey the water to agricultural sites. The canals became infested with snails that carry the disease schistosomiasis (Snail fever). This disease has always been a problem in Egypt because the tremendous expanse of water in irrigation canals now provides happy homes for these snails. The disease is debilitating and so prevalent in parts of Egypt that virtually the entire population of some areas may have been affected by it (Botkin and Keller, 2003).

The research for comfort and the satisfaction of human needs has brought about certain forms of development. Among this development are development tailored around the use of rivers. The need for good water that is safe for drinking cannot be overemphasized, and also for the modern day man, the use of electricity cannot be ruled out. Dam construction is very important in the sense that it provides water and also serves as a source for generating power (Hydro-Electric Power) for the use of man. Though this development is very important, it has altered the general pattern of flow of rivers and this has affected a number of things, among which is the hydrometeorology, settlement pattern, socioeconomy of the area among others. In the construction of dams, people have been displaced, agricultural land have been abandoned for the fear of flood, companies cannot dream of citing industries in these areas because of the fear of hazards, the pattern of settlement has taken a particular form thus limiting what could be done in the area (Chambers, 1998).

All of these and more are problems that have resulted due to the construction of Jebba dam along the River Niger. This paper is aimed at assessing the extent to which Jebba dam has affected the socio-economic activities of people downstream. The objectives are to:

Identify changes in downstream river quality caused by altered flow pattern;

Assess the effect of altered flow pattern on farming activities;

Assess the effect of altered flow pattern on fishing activities; 
Assess the effect of dam construction on settlement;

\section{Description of Study Area}

Jebba dam is one of the three main dams in Niger State constructed in the year 1984 after an Environmental Impact Assessment (EIA) was carried out on both upstream and downstream impacts in communities and their economic activities including the channel morphology. The communities upstream include Ghajibo, Bukka, Byagi, Eggangi, Ekwa, Karogi, Batagi, Mazhi, etc were resettled because of the EIA (adapted from Suleiman, 2001). It lies on the south bank and at the natural head of navigation of the Niger State, 550 miles $(885 \mathrm{~km})$ from the sea. It is located on latitude $9.168 \mathrm{~N}$ and longitude $4.822 \mathrm{E}$ and has the length of its power house to be 206 meters. The Jebba main dam was constructed as a tail water dam to harness the outflow of Kainji Dam for additional power generation (540MW) and is founded on alluvial sands up to $230 \mathrm{ft}$ (70m) in depth. (Adams, 1985). Soil investigation established the presence of locally loose materials at various depths. Jebba dam is constructed along the River Niger, and the construction led to the evacuation of about 6,000 rural dwellers who were resettled into new settlements. The occupation of the people resettled was either fishing or farming or both. The creation of new lakes also allowed for influx of fishermen into the lake basin.

\section{Rainfall}

Between May and July, the Jebba lake water shed receives in excess of $100 \mathrm{~mm}$ with peak

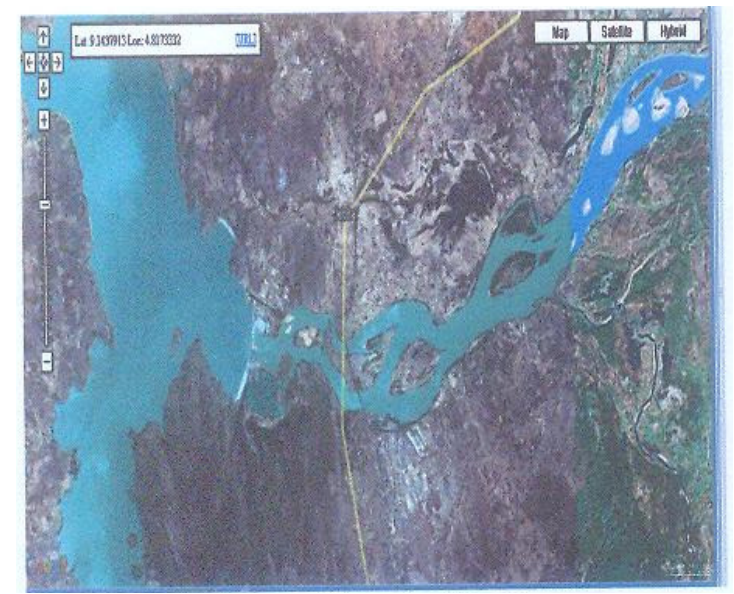

Source: Google Earth value of about $280-300 \mathrm{~mm}$ in July in the Southwest of Jebba and West of Mokwa respectively. There is no part of the watershed that receives less than $180-200 \mathrm{~mm}$ of rainfall in July. August to September constitute the peak of rainy season within Jebba and its environs. Highest of rainfall of over $400 \mathrm{~mm}$ is to be expected in September during normal raining year (Adefolalu \& Oguntoyinbo, 1985).

\section{Temperature}

The creation of the lake modified the relative temperature of the resulting catchments areas; this makes the temperature different as we travel further away from the basin.

\section{Soils}

Soil types within the study area are welldrained shallow to moderately deep. The color varies from very dark gravity brown to dark strong brown or yellow red. The soil in the catchments is derived from pre-existing rock i.e. Precambrian basement complex consisting of gneiss, granite and amphibolies schist.

\section{Topography}

The geology of the study area is typically and essentially the basement complex with prominent outcrops. The complex is mainly granite, the topography is highly undulating. Isolated hills of over $600 \mathrm{~m}$ above sea levels are common while valleys in between can get as low as $400 \mathrm{~m}$ above sea level, the undulating hills are made up of granite rocks while the rocks in the lower terrain are dominated by schist and gneiss (Figures 1 and 2).

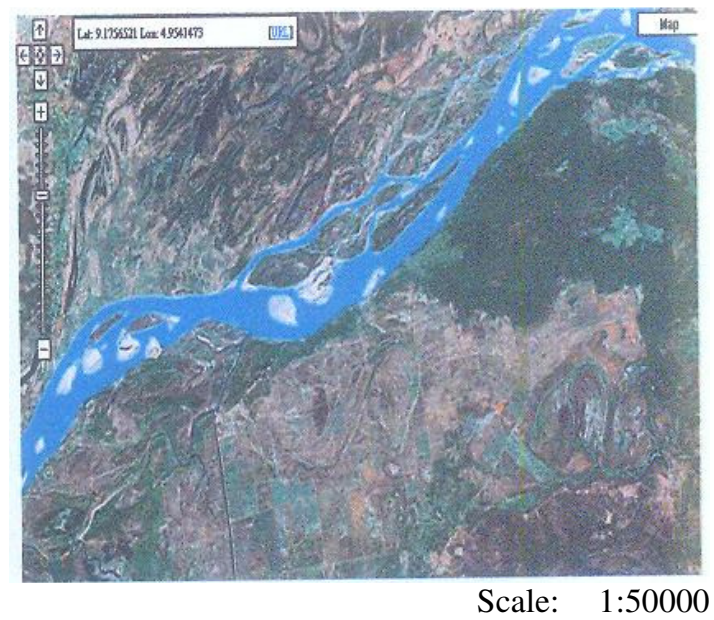

Figures 1a and b: Satellite Image of Jebba Dam and Its Downstream Locations 


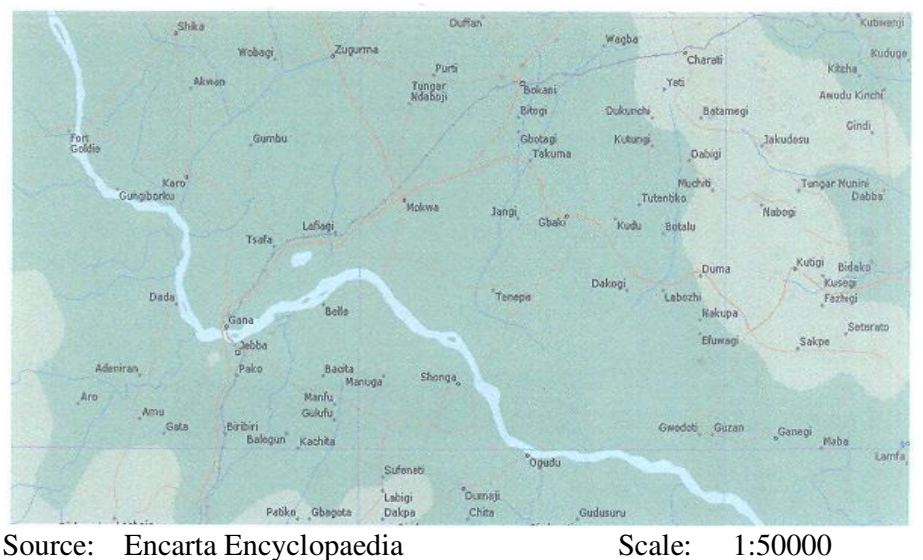

Figure 2: Map of River Niger and Some Downstream Communities

\section{Materials and Methods \\ Reconnaissance Survey}

Reconnaissance survey was carried out on the field to ascertain some features and practices such as the displaced settlements and flooded farmlands in the study area.

\section{Sampling Technique}

Questionnaires were administered to randomly selected people in seven (7) selected villages in the downstream locations. A total of 200 copies of the questionnaires each were distributed to each selected village. Simple random sampling was used in the selection of villages since the study area is a rural settlement whose houses are scattered. The questionnaires administered was used to gather information on occupation of the residents, water supply, electricity supply, major environmental problems they are affected by among others.

\section{Results and Discussion}

The summary information as extracted from the administered questionnaire is presented in Table 1.

Table 1: Summary of Questionnaire Results

\begin{tabular}{|c|c|c|c|c|c|c|c|c|c|c|}
\hline \multirow{2}{*}{ Villages } & \multirow{2}{*}{$\begin{array}{c}\text { Housing } \\
\text { Units }\end{array}$} & \multicolumn{2}{|c|}{ Road Accessibility } & \multicolumn{2}{|c|}{ Occupation } & \multicolumn{2}{|c|}{ Power Supply (PHCN) } & \multicolumn{2}{|c|}{ Settlement Pattern } & \multirow{2}{*}{$\begin{array}{c}\text { Population } \\
\text { (Appr } \\
\text { Value) }\end{array}$} \\
\hline & & Before & After & Before & After & Before & After & Before & After & \\
\hline $\begin{array}{c}\text { Gungu } \\
\text { (Natives) }\end{array}$ & 270 & $\begin{array}{c}\text { Not } \\
\text { Motorable }\end{array}$ & Motorable & $\begin{array}{l}\text { Fishing/ } \\
\text { Farming }\end{array}$ & $\begin{array}{l}\text { Fishing/ } \\
\text { farming }\end{array}$ & $\begin{array}{c}\text { Not } \\
\text { Connected }\end{array}$ & Connected & Dispersed & Linear & 3200 \\
\hline $\begin{array}{c}\text { Gana } \\
\text { (Settlers) }\end{array}$ & 250 & $\begin{array}{c}\text { Not } \\
\text { Motorable }\end{array}$ & Motorable & Trading & $\begin{array}{l}\text { Trading/ } \\
\text { civil } \\
\text { servant }\end{array}$ & $\begin{array}{c}\text { Not } \\
\text { Connected }\end{array}$ & Connected & Dispersed & Nucleated & 3000 \\
\hline Fanga & 180 & $\begin{array}{c}\text { Not } \\
\text { Motorable }\end{array}$ & $\begin{array}{l}\text { Accessible } \\
\text { by } \\
\text { motorcycle }\end{array}$ & $\begin{array}{l}\text { Fishing/ } \\
\text { Farming }\end{array}$ & $\begin{array}{c}\text { Fishing/ } \\
\text { farming/ } \\
\text { Trading/ } \\
\text { civil } \\
\text { servant }\end{array}$ & $\begin{array}{c}\text { Not } \\
\text { Connected }\end{array}$ & $\begin{array}{c}\text { Not } \\
\text { Connected }\end{array}$ & Dispersed & Nucleated & 1500 \\
\hline Bele & 130 & $\begin{array}{c}\text { Not } \\
\text { Motorable }\end{array}$ & $\begin{array}{c}\text { Accessible } \\
\text { by canoe) }\end{array}$ & $\begin{array}{l}\text { Fishing/ } \\
\text { Farming/ } \\
\text { Trading }\end{array}$ & $\begin{array}{l}\text { Fishing/ } \\
\text { Farming/ } \\
\text { Trading }\end{array}$ & $\begin{array}{c}\text { Not } \\
\text { Connected }\end{array}$ & $\begin{array}{c}\text { Not } \\
\text { Connected }\end{array}$ & Dispersed & Linear & 1100 \\
\hline Bere & 120 & $\begin{array}{c}\text { Not } \\
\text { Motorable }\end{array}$ & $\begin{array}{l}\text { Accessible } \\
\text { by canoe }\end{array}$ & $\begin{array}{l}\text { Fishing/ } \\
\text { Farming/ } \\
\text { Trading }\end{array}$ & $\begin{array}{l}\text { Fishing/ } \\
\text { Farming/ } \\
\text { Trading }\end{array}$ & $\begin{array}{c}\text { Not } \\
\text { Connected }\end{array}$ & $\begin{array}{c}\text { Not } \\
\text { Connected }\end{array}$ & Dispersed & Nucleated & 900 \\
\hline Gaba & 130 & $\begin{array}{c}\text { Not } \\
\text { Motorable }\end{array}$ & $\begin{array}{c}\text { Accessible } \\
\text { by canoe }\end{array}$ & $\begin{array}{l}\text { Fishing/ } \\
\text { Farming/ } \\
\text { Trading }\end{array}$ & $\begin{array}{l}\text { Fishing/ } \\
\text { Farming/ } \\
\text { Trading }\end{array}$ & $\begin{array}{c}\text { Not } \\
\text { Connected }\end{array}$ & $\begin{array}{c}\text { Not } \\
\text { Connected }\end{array}$ & Dispersed & Nucleated & 1100 \\
\hline Baru & 130 & $\begin{array}{c}\text { Not } \\
\text { Motorable }\end{array}$ & $\begin{array}{l}\text { Accessible } \\
\text { by } \\
\text { motorcycle } \\
\text { and canoe }\end{array}$ & $\begin{array}{c}\text { Fishing/ } \\
\text { Farming/ } \\
\text { Trading }\end{array}$ & $\begin{array}{l}\text { Fishing/ } \\
\text { Farming/ } \\
\text { Trading }\end{array}$ & $\begin{array}{c}\text { Not } \\
\text { Connected }\end{array}$ & $\begin{array}{c}\text { Not } \\
\text { Connected }\end{array}$ & Dispersed & Nucleated & 1100 \\
\hline
\end{tabular}




\section{Occupation of Villagers}

The predominant occupation in most of the communities was formerly farming and fishing Baru constitute the highest percentage of farmers (almost $70 \%$ ) but due to altered flow pattern of the river, trading also became an important occupation in the communities. Other occupation include craftsmen and civil servants in Gungu and Gana communities most of whom work with Jebba Sub Station (Figure 3).

\section{Effects of Dams on Occupation of Residents}

From figure 4, the residents in the downstream communities have been disturbed by the construction of the dam. Some have had to change occupation while others had to look for another source of income to support themselves and their families. In Gungu community $44 \%$ of the inhabitants' occupation was affected by the construction of the dam, $40 \%$ in Gana and 50\% in Fanga. In Bele and Gaba only $10 \%$ was affected while Baru and Bere had 5\% and 25\% respectively. This shows that a considerable number of people in these communities have their source of livelihood affected as a result of the construction of the dam. The result is in line with Tchotsoua et al. (2008), which states that While many have benefited from the services which the Lagdo Dam provides, its construction and operation have had considerable negative societal and environmental consequences. The adverse effects on populations include displaced families, host communities where families are resettled, especially those downstream of the dam, whose livelihood and access to resources are affected in varying degrees by altered river flows and ecosystem fragmentation.

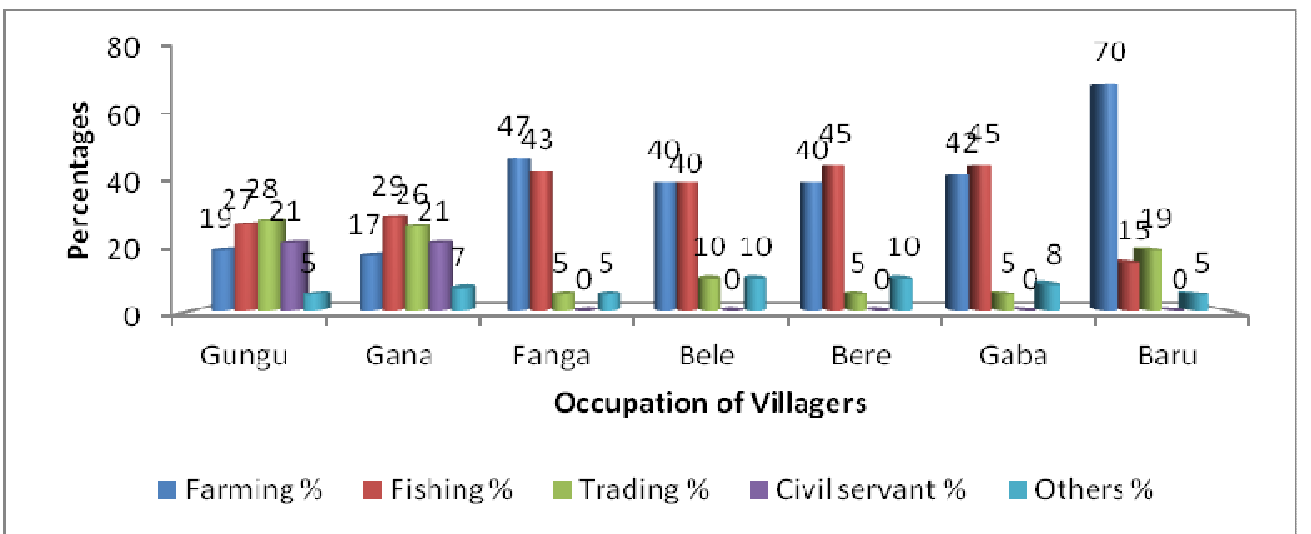

Figure 3: Occupation of Villagers in Percentages

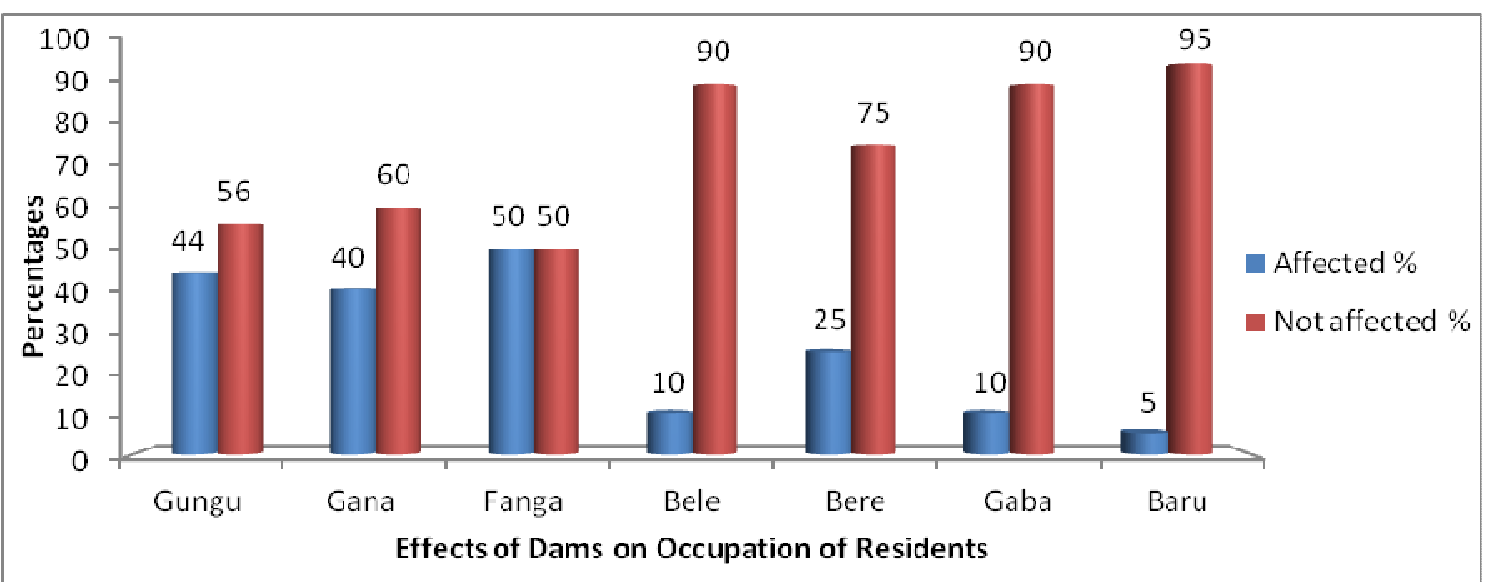

Figure 4: Effects of Dams on Occupation of Residents 
Major Environmental Hazards in Each Community

Communities at the downstream of Jebba dam are affected by flood and soil erosion. Other environmental hazards like desertification, land, air and water pollution are not experienced in the area. This is justified from table 2:

Table 2: Major Environmental Hazards in Each Community

\begin{tabular}{|l|l|l|l|l|l|l|l|}
\hline Name & Flood & $\begin{array}{l}\text { Soil } \\
\text { erosion }\end{array}$ & Desertification & $\begin{array}{l}\text { Land } \\
\text { pollution }\end{array}$ & $\begin{array}{l}\text { Air } \\
\text { pollution }\end{array}$ & $\begin{array}{l}\text { Water } \\
\text { pollution }\end{array}$ & $\begin{array}{l}\text { Noise } \\
\text { pollution }\end{array}$ \\
\hline Gungu & Present & Present & - & - & - & - & \\
Gana & Present & Present & - & - & - & - & Present \\
Fanga & Present & Present & - & - & - & - & - \\
Bele & Present & Present & - & - & - & - & - \\
Bere & Present & Present & - & - & - & - & - \\
Gaba & Present & Present & - & - & - & - & - \\
Baru & Present & Present & - & - & - & - & - \\
\hline
\end{tabular}

\section{Frequency of Hazards}

The two major environmental hazards experienced in the downstream communities occur annually. Flood is aggravated when spill way gates are opened. Soil erosion is also pronounced during this period.

Table 3: Frequency of Occurrence of Hazards

\begin{tabular}{|c|c|c|c|}
\hline Name of village & Flood & Soil erosion & Noise pollution \\
\hline Gungu & Annually & Annually & Occasionally \\
\hline Gana & Annually & Annually & Occasionally \\
\hline Fanga & $\begin{array}{l}\text { Occasionally (especially } \\
\text { when spill gates are } \\
\text { opened }\end{array}$ & Annually & - \\
\hline Bele & $\begin{array}{l}\text { Occasionally (especially } \\
\text { when spill gates are } \\
\text { opened }\end{array}$ & Annually & - \\
\hline Bere & $\begin{array}{l}\text { Occasionally (especially } \\
\text { when spill gates are } \\
\text { opened }\end{array}$ & Annually & - \\
\hline Gaba & $\begin{array}{l}\text { Occasionally (especially } \\
\text { when spill gates are } \\
\text { opened }\end{array}$ & Annually & - \\
\hline Baru & $\begin{array}{l}\text { Occasionally (especially } \\
\text { when spill gates are } \\
\text { opened }\end{array}$ & Annually & - \\
\hline
\end{tabular}

Evidence of Development in the Downstream Communities

From Figure 5, it can be seen that there has been no physical development in some of the downstream communities since construction of the dam except for Gungu and Gana communities about $5 \mathrm{~km}$ from the dam site. 


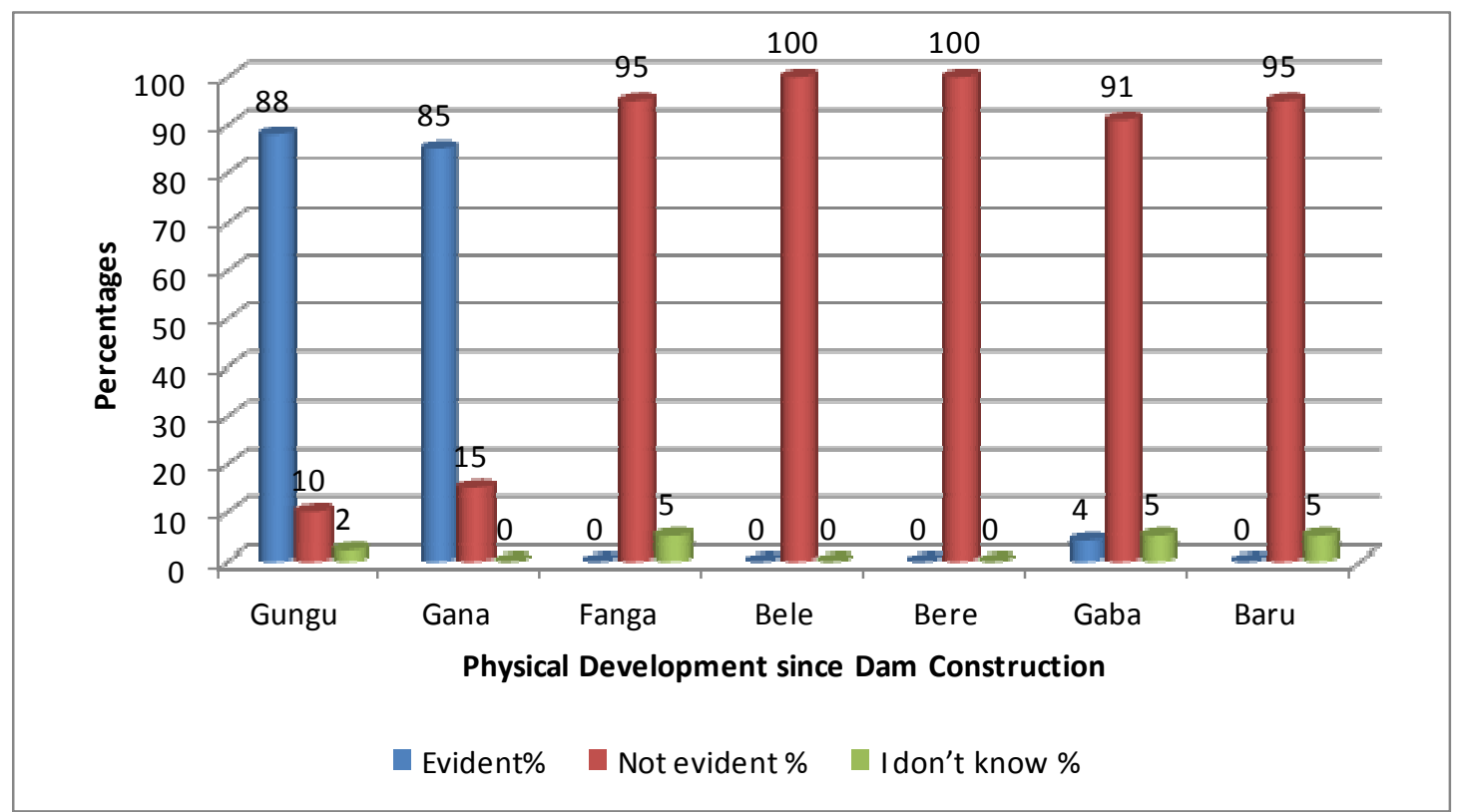

Figure 5: Physical Development since Construction of Dam

\section{Government Compensation to Downstream Communities}

Each time floodgates are opened and agricultural land destroyed, communities close to the dam are compensated while communities farther away from the dam are often not. This can be seen from Figure 6.

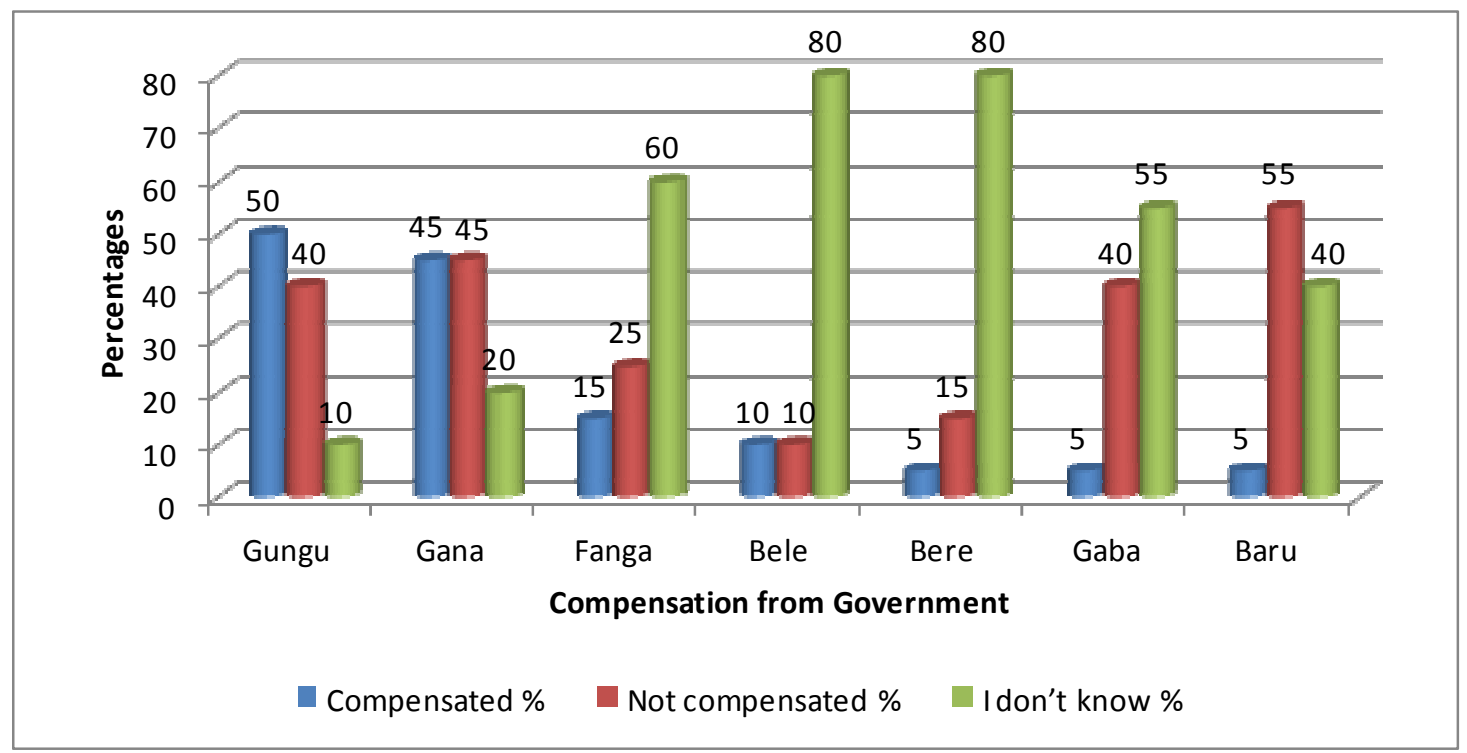

Figure 6: Compensation from government when flood gates are opened and farmlands destroyed

\section{Adequacy of Compensation}

All the communities confirmed that the compensation is not adequate .Between $22 \%$ to almost $100 \%$ respondents believed that the compensation is very poor because none of them collected more than two thousand naira N2, 000 as compensation for relocation of houses and farmland, this amount could not and 
cannot build a single room for a house hold before and at present that's why it is considered not adequate. Figure 7.

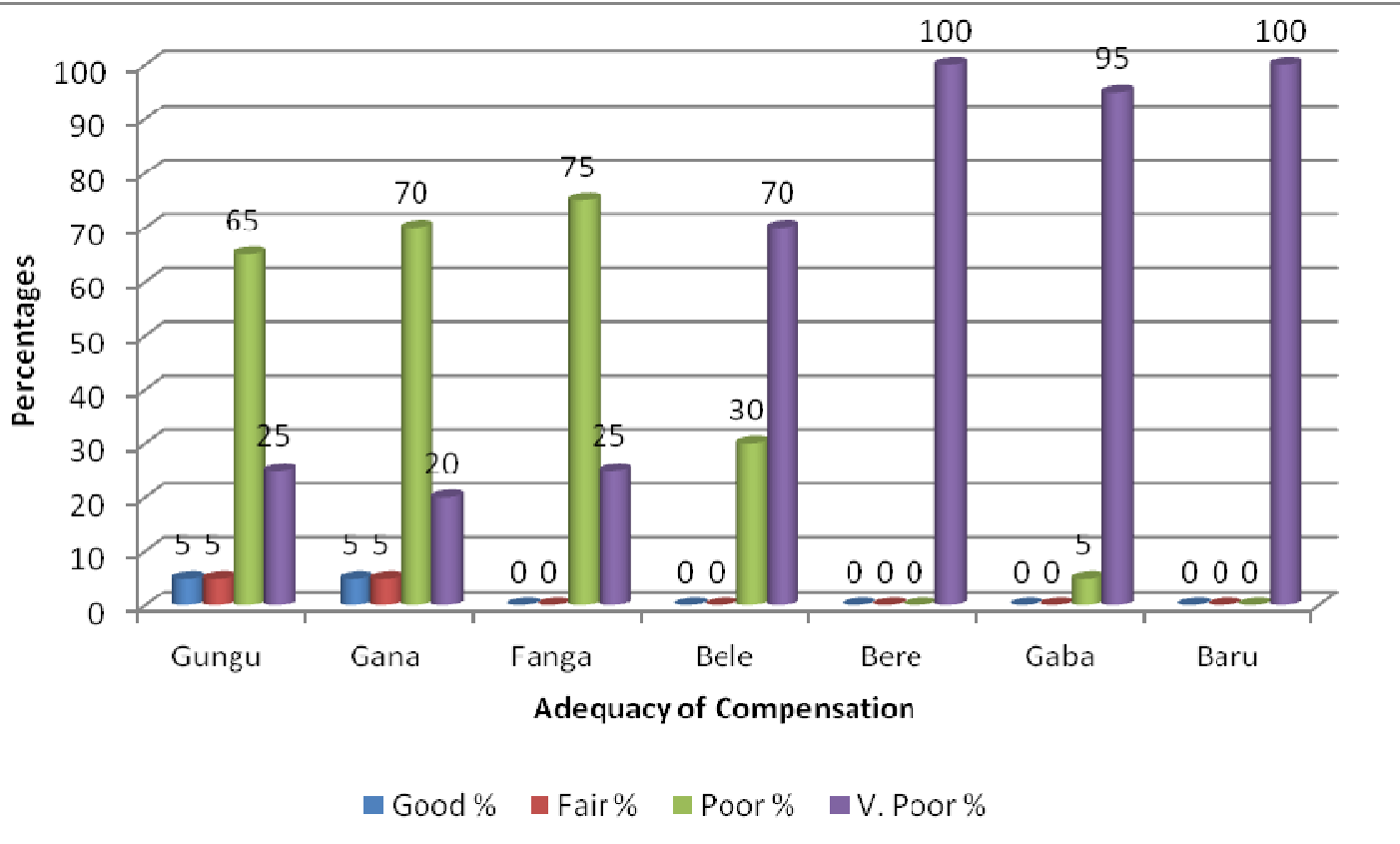

Figure 7: Adequacy of Compensation

\section{Opening of floodgates}

As seen in Figure 8, the communities closer to the dam agreed that they are told before floodgates are opened so that they can relocate. The communities farther away say they are not informed before floodgates are opened.

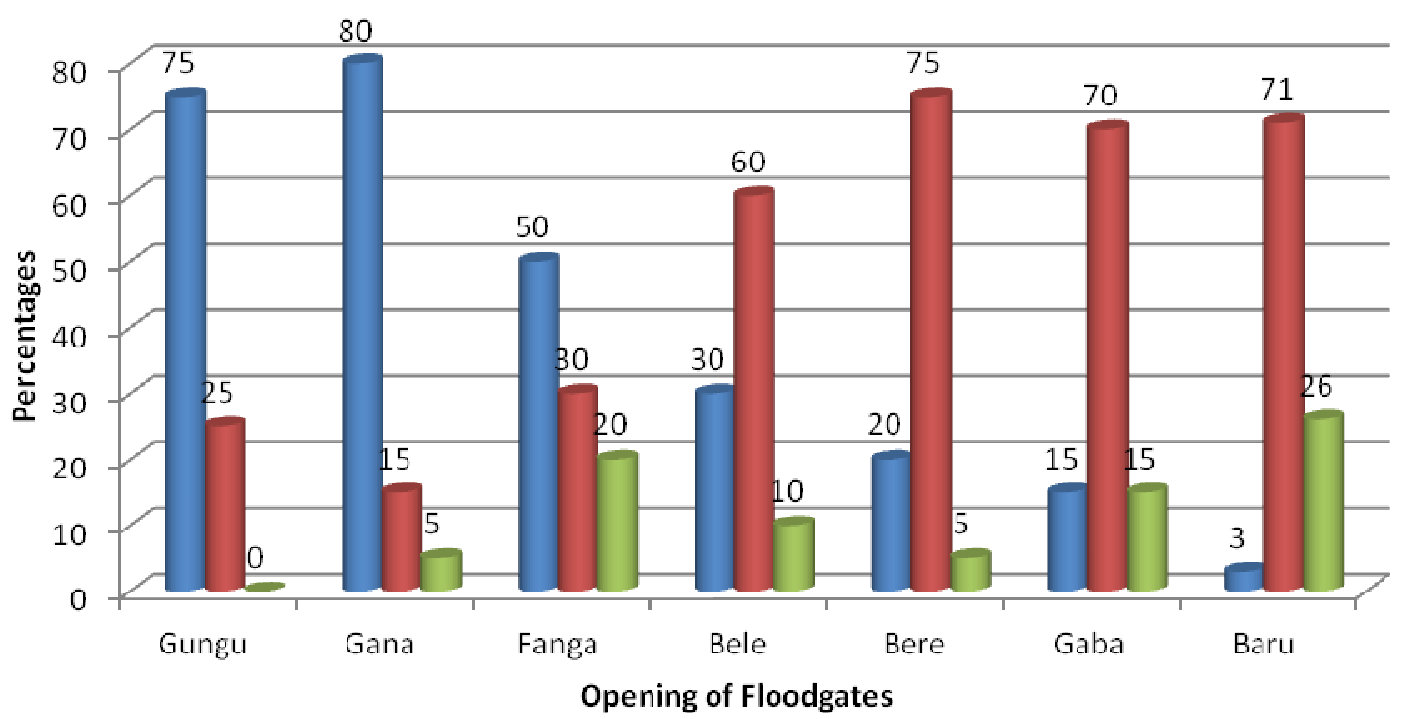

Informed \% Not informed \% I don't know \%

Figure 8: Opening of Floodgates 


\section{Last time flood gates were opened}

The floodgates were opened last in 2008 when the rains were at its peak and the wall of the dam was threatened. This affected all farming and fishing communities in the downstream communities.

\section{Effects of Jebba Dam on Farming Communities Downstream}

From Figure 9, it can be seen that some of the respondents have had a change from farming to trading and other forms of craft due to destroyed and threatened land. Salami (2007) reported that in 1994 over 2,260 ha of sugar cane fields were flooded and remained inundated for over six weeks. The flood damaged irrigation and water conveyance structures, washed away the existing flood protection embankments, roads and caused displacement of settlements and communities along River Niger. In 1998 and 1999 the flood problem re-occurred and led to enormous losses. The occurrences of flooding is now annually. Tada-Shonga rice irrigation project is also located within the flood plain of the River Niger downstream of Jebba dam. The areas have flat topography and between the months of August and September, the water table comes within the rooting zone or even to the surface. Very high discharges of Niger River in September and December causes rise of levels and overflow of river banks there by leading to flooding. Other affected places include Shoga, Patigi, Lafiagi and their environs in Kwara State. Many reports indicated the extent of the damages as a result of indiscriminate release of excess water from the reservoirs at their upstream and this incidence has become annual event.

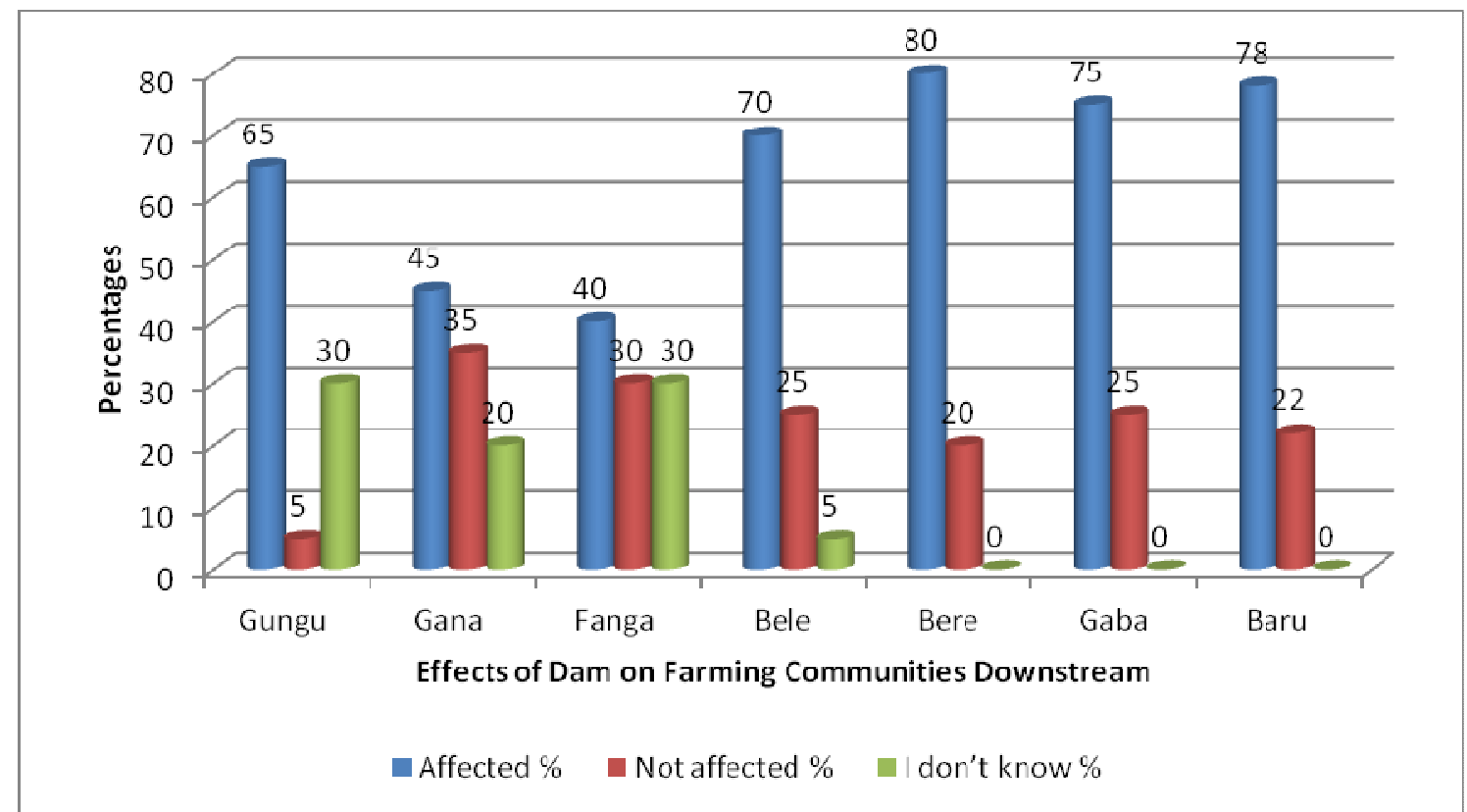

Figure 9: Effects of Dam on Farming Communities Downstream

\section{Effects of Altered Flow Pattern on River Resources}

The river resources in the downstream communities have been affected; therefore, aquatic animals and the socio-economic activities of man have been affected. Gaba, Bere, etc are the most affected communities while Gana are least affected communities. See the figure 10: 
The Socio-economic Characteristics of Communities at the Downstream ADEBOLA et al.

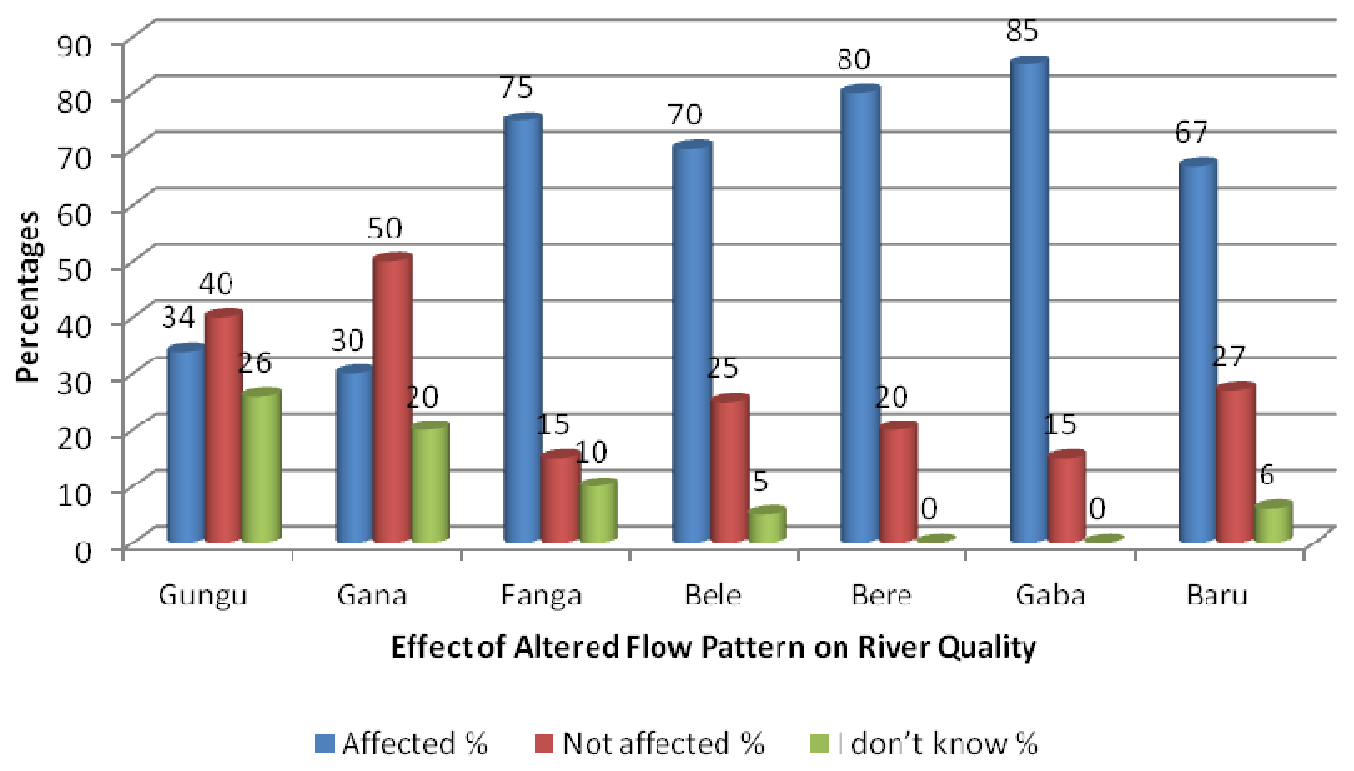

Figure 10: Does the Altered Flow Pattern Have Effect on River Quality

\section{Effects of Altered Flow Pattern on Fishing Communities Downstream}

Figure 11 shows that much of the water that should get to the downstream communities has been trapped within the walls of the dam. This has made fish survival and number of fish to reduce in downstream communities.

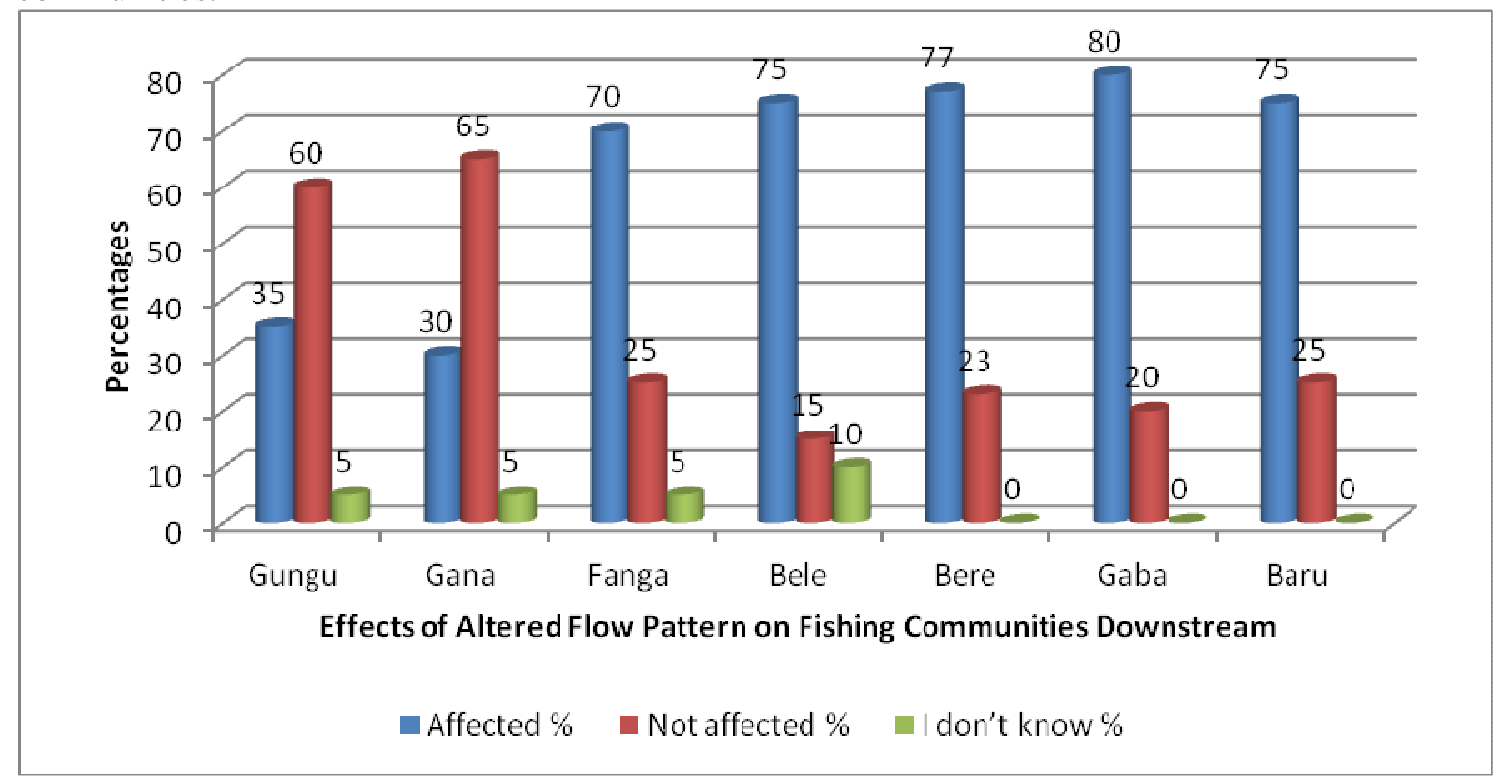

Figure 11: Effects of Altered Flow Pattern on Fishing Communities Downstream 


\section{Implications of the Dam Construction to the Communities Downstream}

As a result of the construction of the Jebba Dam farmlands and fishing activities were affected in the downstream communities thus, reducing the economic returns of the inhabitants. There have been indiscriminate displacements of settlements along the downstream due to flood activities associated with dammed rivers.

The alteration of river regime has affected the aquatic life, as the intensity of flow in the downstream sector of the river is regulated by the dam authority. Indeed, comparison studies show that while larger and deeper reservoirs yield fish, on average, at $10-50 \mathrm{~kg} / \mathrm{ha} / \mathrm{y}$, flood-plains average 200-2000 kg/ha/y (Jackson and Marmulla, 2000). The three key factors supporting this increased productivity in floodplain rivers are the extent of the flooded area (Halls and Welcomme, 2004; Tockner and Stanford, 2002), flood duration (Koel and Sparks, 2002), and timing of the flood peak (Hoggarth et al., 1999).

When flood-plains are regularly connected to their rivers, they are not only more productive but house the majority of the river's species. In the lower Rhine and Meuse rivers, for example, 70\% of the species are found exclusively in the floodplain lakes (Van Den Brink et al., 1996). Through the survival game of evolution, the advantages of flood-plain habitats have caused many fish species to become so specialised in their genetic make-up that they do not, and cannot, spawn anywhere but in the flood-plain. Ironically, those same genes that enable them to thrive and grow far more quickly by exploiting flood-plain habitats cause their populations to crash when an upstream dam eliminates a river's floods.

\section{Conclusion}

The result from the findings revealed that changes occurred in occupation of the inhabitants such as trading, fishing, civil service, craftsmen etc. due to dam construction. It was also discovered that environmental hazards such as land, air, noise pollutions are not experienced while Fanga, Bele, Bere, Gaba and Baru communities experience annual soil erosion as well as occasional flood when spill gates are opened as seen in table 3. Water resources were also affected. The affected communities were also not adequately compensated and only two communities (Gungu and Gana) are connected with electricity.

\section{Recommendations}

All villages that are affected by the activities of the dam should be connected to the national grid; this will enhance the socio-economic activities in the area.

It is suggested as a principle that 'a programme to monitor the impacts of dam development (particularly in downstream communities) should be an integral element of the planning process, and should be matched by resources to mitigate impacts not addressed fully by the planning processes

Human rights and key socio-economic parameters need to be monitored, at least along the river valley in the early years of dam operation. These parameters should be disaggregated enough in other to capture and address imbalances in the distribution of socioeconomic costs and benefits of dams.

It is important to generate gender-specific indicators that take into account the varied locations of men and women at all levels of society. Special financial resources human and institutional resources should be built-in the dam project design to address unanticipated social and economic problems emerging from the monitoring activities.

Affected people who feel they are experiencing negative impacts should be entitled to request quick appraisals, inspections, and specific research to document the seriousness and scope of the problems and to find lasting solutions.

\section{References}

Adams, W.M. (1985). The Downstream Impacts of Dam Construction: A Case Study from Nigeria. Transactions of the Institute of British Geographers N.S. 10, 292-302

Adams, W.M. (2000). Social Impacts of Large Dams: Equity and Distributional Issues, Report to

World Commission on Dams. Thematic Review II Social Impacts of Large Dams; Equity and Distributional Issues. 
Adefolalu, D.O. and Oguntoyinbo, J.S. (1985). On Rainfall Distribution and Agricultural Planning. Journal of Tropical Geography, 1(ii): 9-13.

Botkin, D.B. and Keller, E.A. (2003). Environmental Science. John Wesley Sons, Inc.

Carney, D. (1998). Sustainable rural livelihoods: What contributions can we make? London: Department for International Development.

Chambers, R. (1998). Sustainable Rural Livelihoods: A Key Strategy for people, environment and development, pp. 1-17. In: Controy $\mathrm{C}$, Litvonoff $\mathrm{M}$ (Eds): The Greening of Aid: Sustainable Livelihoods in Practice. Earthscan, London.

Halls, A. and Welcomme, R. (2004). Dynamics of river fish populations in response to hydrological conditions: A simulation study. River Research and Applications 20(8), 985-1000.

Hoggarth, D.D., Cowan, V.J., Halls, A., AeronThomas, M; McGregor, J.A.; Garaway, C.A.; Payne, A.I. and Welcomme, R.L. (1999). Management guidelines for Asian flood-plain river fisheries. Part 1: A spatial, hierarchical and integrated strategy for adaptive co-management. FAO Fisheries Technical Paper (384)1. Rome, Italy: FAO.

Jackson, D. and Marmulla, G. (2000). The influence of dams on river fisheries. In Berkamp, G., McCartney, M., Dugan, P., McNeely, J. and Acreman, M. (Eds), Thematic review II.1: Dams, ecosystem functions and environmental restoration. Cape Town, South Africa: World Commission on Dams.
Koel, T.M. and Sparks, R.E. (2002). Historical patterns of river state and fish communities as criteria for operations of dams on the Illinois river. River Research and Applications 18(1), 3-19.

National Population Commission (2006), Census Figures. Online edition,

http://services.gov.ng/national-populationcommission retrieved Nov 182010

Nwafor, J.C. (2006). Environmental Impact Assessment for Sustainable Development. The Nigerian Perspective. Published by Environmental and Development Policy (EDPCA).

Salami, A.W. (2007). Operational performance of water management models for a hydropower system under reservoir inflow forecasts. A Ph.D. Thesis report presented to the Post graduate School, University of Ilorin, Ilorin, Nigeria.

Tchotsoua M., Moussa, A. and Jean-Marie, F. (2008). The Socio-Economic Downstream Impact of Large Dams: A Case Study from an Evaluation of Flooding Risks in the Benue River Basin Downstream of the Lagdo Dam (Cameroon), Ann Arabor, MI publishing, Michigan. Journal of African Studies 5(1): 16-19.

Tockner, K. and Stanford, J. (2002). Riverine flood plains: Present state and future trends. Environmental Conservation 29(3): 308330.

Van Den Brink, F.W.B.; Van Der Velde, G.; Buijse, A.D. and Klink, A.G. (1996). Biodiversity in the Lower Rhine and Meuse river-flood-plains: Its significance for ecological river management. Netherlands Journal of Aquatic Ecology 30(2-3), 129149. 